\title{
The Glucose-Regulated MiR-483-3p Influences Key Signaling Pathways in Cancer
}

\author{
Felice Pepe ${ }^{1}$, Rosa Visone ${ }^{2,3}$ and Angelo Veronese ${ }^{2,3, *}$ \\ 1 Comprehensive Cancer Center, The Ohio State University, Columbus, OH 43210, USA; \\ Felice.Pepe@osumc.edu \\ 2 Ageing Research Center and Translational Medicine-CeSI-MeT, 66100 Chieti, Italy; r.visone@unich.it \\ 3 Department of Medical, Oral and Biotechnological Sciences, G. d'Annunzio University Chieti-Pescara, \\ 66100 Chieti, Italy \\ * Correspondence: a.veronese@unich.it; Tel.: +39-0871-541561; Fax: +39-0871-541511
}

Received: 27 April 2018; Accepted: 29 May 2018; Published: 4 June 2018

\begin{abstract}
The hsa-mir-483 gene, located within the IGF2 locus, transcribes for two mature microRNAs, $m i R-483-5 p$ and $m i R-483-3 p$. This gene, whose regulation is mediated by the the CTNNB1/USF1 complex, shows an independent expression from its host gene IGF2. The miR-483-3p affects the Wnt $/ \beta$-catenin, the TGF- $\beta$, and the TP53 signaling pathways by targeting several genes as CTNNB1, $S M A D 4, I G F 1$, and BBC3. Accordingly, $m i R-483-3 p$ is associated with various tissues specific physiological properties as insulin and melanin production, as well as with cellular physiological functions such as wounding, differentiation, proliferation, and survival. Deregulation of $m i R-483-3 p$ is observed in different types of cancer, and its overexpression can inhibit the pro-apoptotic pathway induced by the TP53 target effectors. As a result, the oncogenic characteristics of $m i R-483-3 p$ are linked to the effect of some of the most relevant cancer-related genes, TP53 and CTNNB1, as well as to one of the most important cancer hallmark: the aberrant glucose metabolism of tumor cells. In this review, we summarize the recent findings regarding the $m i R-483-3 p$, to elucidate its functional role in physiological and pathological contexts, focusing overall on its involvement in cancer and in the TP53 pathway.
\end{abstract}

Keywords: $m i R-483-3 p$; metabolism; TP53; CTNNB1; chemoresistance; cancer; miR-145-5p

\section{Introduction}

MicroRNAs (miRNAs) are noncoding RNAs of about 18-28 ribonucleotide lengths, which modulate gene expression by inhibiting their translation or promoting their mRNA degradation [1]. MicroRNAs play a critical function in the homeostasis of central cellular processes, and their deregulation in human neoplasm has mainly been proven [2-4].

The hsa-miR-483 gene is a mammal-conserved microRNA that resides at the 2nd intron of the human insulin growth factor 2 (IGF2) gene at the 11p15.5 chromosome region [5] (Figure 1). The genomic localization of this microRNA is of particular interest. Indeed, the IGF2 is an imprinted gene, expressed by the paternal allele to produce an important fetal insulin growth factor. Defects in the imprinting of the IGF2 locus are observed in the Beckwith-Wiedemann syndrome, which increases the incidence of pediatric malignancies as nephroblastoma (Wilms' tumor), hepatoblastoma, and rhabdomyosarcoma [6]. Moreover, also adult tumors are linked to genetic and epigenetic defects of this imprinted locus such as colorectal cancer (CRC), hepatocellular carcinoma (HCC) and breast cancer (BrCA) [7,8] pointing out to IGF2 as the main oncogene of this genomic locus. However, a transgenic mouse model for IGF2 (without including the miR-483 gene) exhibited several features associated with the Beckwith-Wiedemann syndrome without association to any neoplasia [9]. These data suggested 
the IGF2/miR-483 locus as the oncogenic unit of the $11 p 15.5$ chromosome region instead of the IGF2 alone [10-12].

The $h s a-m i R-483$ gene encodes for two mature miRNAs: $m i R-483-5 p$ and $m i R-483-3 p$. Both are found deregulated in different types of cancer. MiR-483-5p is abnormally observed in the serum of cancer patients suggesting its possible utilise as cancer biomarker in various malignancies [13-26]. On the other hand, the miR-483-3p is extensively studied concerning its function on different cancer-related pathways as chemoresistance, immune-evasion, cancer metabolism and resistance to apoptosis by targeting several genes (Table 1).

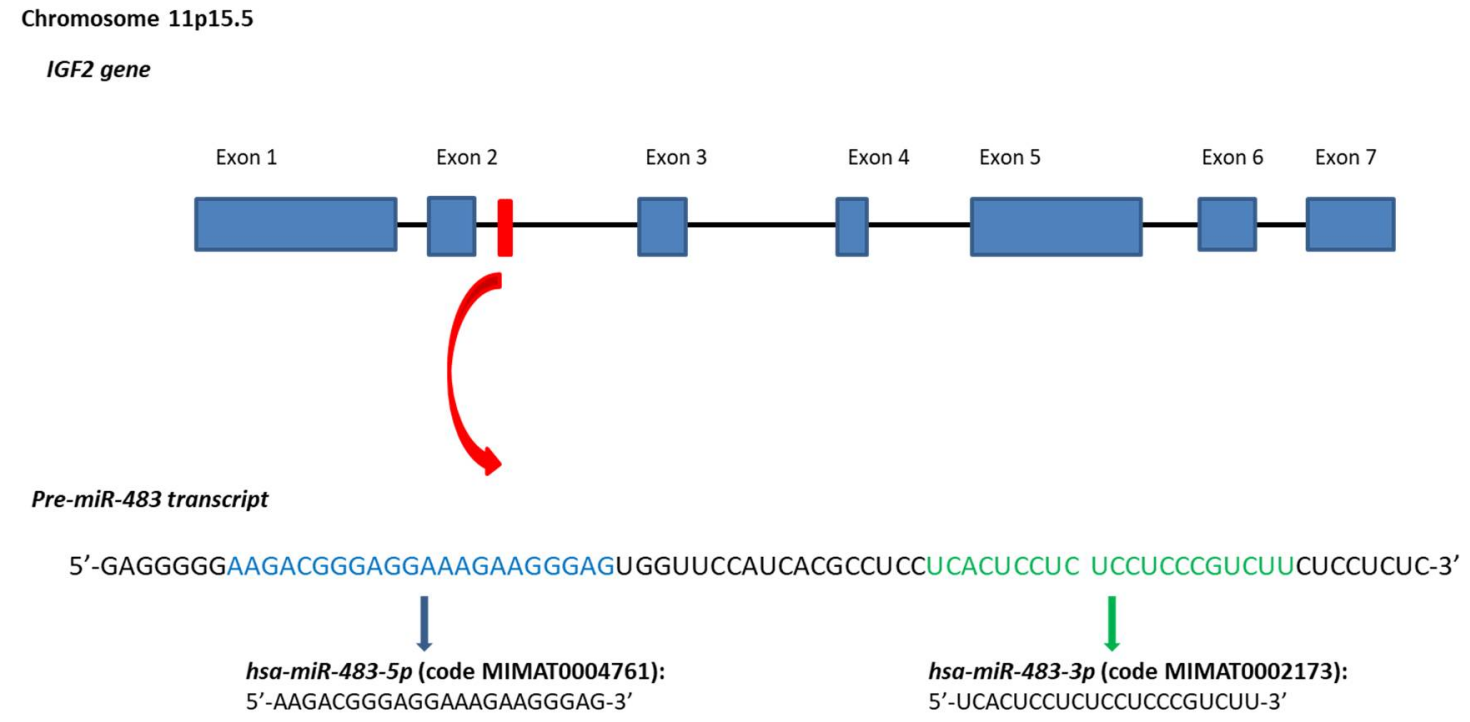

Figure 1. Stem-loop sequence of the $h s a-m i R-483$ and mature miRNAs. In the Figure are reported genomic position, sequence of the $h s a-m i R-483$ gene. Sequences data from miRBase database [27-31].

Table 1. miR-483-3p verified targets. (h), (r) and (m) indicate respectively human, rat and murine tissues.

\begin{tabular}{ccrc}
\hline Gene & Tissues & Cells/Cell Lines & References \\
\hline AANAT & Pineal gland (h), (r) & Neonatal pinealocytes (r), HEK293 & {$[32]$} \\
BBC3PUMA & Kidney, Colon, Liver (h) & HEK293, HCT116, HepG2 & {$[12]$} \\
BRCA1 & Liver (m) & & {$[33]$} \\
CDC25A & Keratinocytes (h) & HEK293, HCT116 & {$[34]$} \\
CTNNB1 & Kidney (h), Colon (h) & HCT116, SW480 & {$[36]$} \\
DLC1 & Colon (h) & & {$[37]$} \\
IGF1 & Natural Killer cells (h), Cardiomyocites (m) & & {$[38]$} \\
MK2 & Keratinocyte (h) & & {$[38]$} \\
MKI67 & Keratinocyte (h) & & {$[39]$} \\
PGAM1 & Kidney (h) & & {$[40]$} \\
PRKCA & Ovarian (h) & IGROV-1 & {$[41]$} \\
SMAD4 & Pancreas (h) & SW1990, PANC1 & {$[38]$} \\
YAP1 & Keratinocyte (h) & & \\
\hline
\end{tabular}

\section{The Regulation of Transcription of $M i R-483-3 p$}

\subsection{The IGF2/MiR-483 Locus}

MiR-483 maps at 11p15.5, a chromosomal region defined Multiple Tumor-Associated Chromosomes Region 1 (MTACR1). Genetic and epigenetic abnormalities in this chromosomal region have been associated with various human neoplasms and with the cancer-predisposing Beckwith-Wiedemann syndrome (BWS). In particular, genetic aberrations at $11 \mathrm{p} 15$ are typically detected in more than $80 \%$ of Wilms' tumors [42] and, albeit, less frequently, in other more common adult neoplasms [43-46]. 
The miR-483-3p host gene, IGF2, is part of the IGF2/H19 genetic locus. This locus is one of a few hundred imprinted DNA regions in mammals and one of the best studied in human. IGF2 is expressed exclusively by the paternal allele whereas the $H 19$ gene is maternally expressed. This allelic specific transcription is dictated by the methylation status of the IGF2/H19 Imprinted Control Region (ICR), a DNA sequence located between these two genes. At the paternal allele, the ICR is methylated whereas in the maternal allele is de-methylated [47]. In cancer, especially in Wilms' tumor, aberrant methylation of the ICR causes the reactivation of the maternal silent IGF2 allele and the silencing of the active H19 maternal allele [8,48-51]. Nevertheless, IGF2 murine transgenic models have highlighted features close to the BWS without tumor predisposition [9]. On the other hand, the Wilms' tumor mouse model published by $\mathrm{Hu}$ et al. was generated by somatic ablation of $\mathrm{Wt1}$ and constitutional bi-allelic expression of the IGF2 entire locus which contain the $m m u$-miR-483 gene [52].

We observed that miR-483-3p is over-expressed in $100 \%$ of Wilms' tumors, and that colorectal, breast and liver cancers exhibit high levels of $m i R-483-3 p$ in about the 30\% of the cases [12]. It was found a positive correlation between the expression of miR-483-3p and IGF2 in different types of cancers as HCC, CRC and Wilms' tumor, suggesting a co-regulation with IGF2. However, HCC samples exhibited the lower coefficient of correlation, several samples showed divergent expression between IGF2 and miR-483-3p. Indeed, it was observed that miR-483-3p could be finely regulated in the HCC cells independently from its host gene IGF2. This independent mechanism of transcription involves DNA methylation, specific transcription factors, and cellular glucose concentration. Here we reported the last discoveries about the $m i R-483-3 p$ regulation.

\subsection{MiR-483-3p and $\beta$-Catenin}

MiR-483-3p expression was found up-regulated in tumors (HCC, CRC, BrCA and Wilms' tumor) [12] that show the $\beta$-catenin (CTNNB1) signaling frequently dysregulated [53-55]. Interestingly an association between the mutational status of genes related to $\beta$-catenin pathway (APC, CTNNB1, and AXIN1) and $m i R-483-3 p$ expression, but not IGF2, was detected in HCC. These observations, together with in vitro experiments showed an exclusive regulation of the $m i R-483-3 p$ expression under the control of $\beta$-catenin transcription factor [35].

However, CTNNB1 itself is a target of $m i R-483-3 p$, triggering a negative regulatory loop. This regulatory mechanism becomes ineffective in cells harboring an activating mutation on the CTNNB1 coding sequence (ser45 deletion). In pathological conditions, this mutation permits to the protein to evade the regulative loop and cause high expression of both elements.

Analysis of the minimal promoter region of the $m i R-483$ located the $\beta$-catenin responsive element closely upstream the microRNA gene and identified it as an E-box motif (CACGTG). This E-box interacts with the basic helix-loop-helix protein upstream stimulatory transcription factor 1 (USF1) which was demonstrated be the co-factor of $\beta$-catenin to regulate the miR-483 gene [35] (Figure 2).

a.

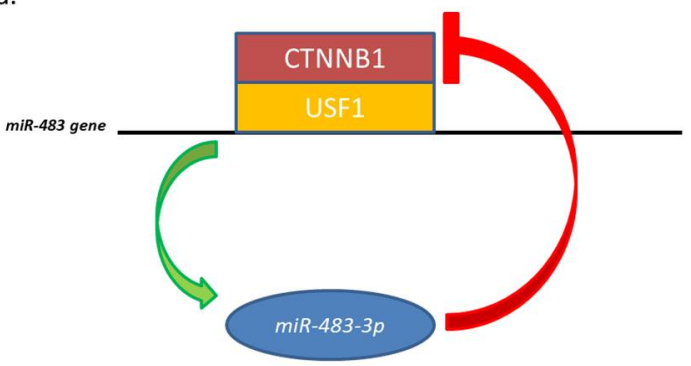

b.

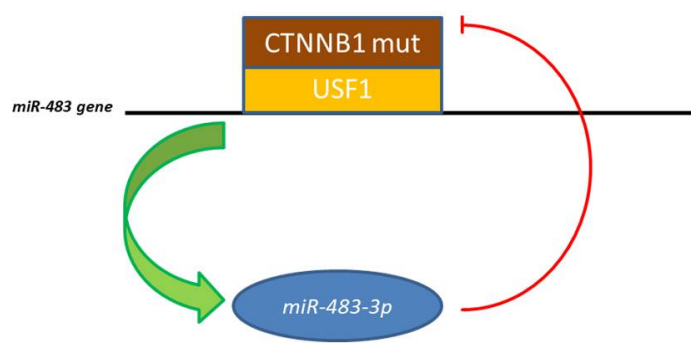

Figure 2. Representation of $m i R-483-3 p$ feedback with the USF1/CTNNB1 complex. (a) Physiological negative feedback; (b) CTNNB1 mutated is no more regulated by $m i R-483-3 p$, which expression increase. 


\subsection{MiR-483 and the Glucose Metabolism}

The association of glucose metabolism to the regulation of $m i R-483-3 p$ is supported by several studies that connect CTNNB1 and USF1 activity to cellular glucose metabolism [56-58] and by the fact that miR-483-3p maps at the INS-IGF2 locus, which is involved in the insulin pathway [7,59]. Moreover, it was observed that the $m i R-483-3 p$ is up-regulated in streptozotocin-induced diabetic mice, and cultured cardiomyocytes mimicking hyperglycemia [60]. Studies on HepG2 cells (Hepatoblastoma cell line) showed that the expression of $m i R-483-3 p$ is significantly affected by the extracellular concentration of glucose [61]. Indeed, $M i R-483-3 p$ expression was reduced by both glucose starvation and treatment with the glucose antagonist 2-deoxy-D-glucose (2-DG). The treatment with 2-DG affected the levels of both $m i R-483-3 p$ and its precursor pri-miR-483 in a concentration-dependent way. Moreover, this regulation was independent of IGF2 expression. Glucose concentration affects the miR-483-3p expression by the $O$-linked $\beta-N$-acetylglucosamine transferase (OGT). OGT protein mediates the addition of a $\mathrm{N}$-acetylglucosamine in an $\mathrm{O}$-glycosidic linkage (O-GlcNAcylation) to protein serine or threonine residues [62,63], and influences several cellular processes such as, RNA transcription [64], insulin signaling [65], Wnt/ $\beta$-catenin signaling [66,67] and mouse embryonic development [68]. This post-translational modification is executed in the cytoplasm, using the activated derivative of the glucose metabolism Uridine diphosphate $N$-acetylglucosamine or UDP-GlcNAc as substrate, and it is commonly considered a cellular nutrient sensor and a metabolic regulator $[69,70]$. OGT contributes to $\beta$-catenin stabilization $[66,67]$ and consequently to the regulation of $m i R-483-3 p$ by the CTNNB1/USF1 complex at the E-box element of the $m i R-483$ promoter. Silencing OGT by siRNA or inhibitors as azaserine, reduces the miR-483-3p expression, and the affinity between USF1 and the E-box sequence. This suggests that OGT is fundamental for the CTNNB1/USF1 complex activity regulation of the $m i R-483-3 p$ expression [61]. However, the authors do not exclude that OGT could influence the $m i R-483-3 p$ expression also by other indirect mechanisms. Indeed, OGT regulates RNA transcription by O-GlcNAcylation of RNA polymerase II [71] and several critical transcription factors such as the bHLH transcription factor MYC proto-oncogene [72].

The decrease of $m i R-483-3 p$ expression, by silencing OGT or by 2-DG treatment, was concomitant with the increasing of $B B C 3$ mRNA. These results suggest that the use of the glucose inhibitors could reactivate the TP53 pathway in those tumors where the over-expression of $m i R-483-3 p$ blocks the apoptotic effector of $B B C 3 /$ PUMA. However, despite promising in vitro results that show the 2-DG able to increase the efficacy of the chemotherapic drug 5-fluorouracil (5-FU); in vivo experiment on NSG mice transplanted with HepG2 cells, revealed that tumor cells with higher miR-483-3p expression were selected during tumor progression regardless the 5-FU/2-DG treatment [61].

\subsection{MiR-483 and DNA Methylation}

It was shown that a fragment of $151 \mathrm{bp}\left(\mathrm{IGF} 2-\mathrm{C}_{\mathrm{BI}}\right)$, immediately upstream miR-483 stem-loop, has strong insulator activity and binds to the CCCTC-binding factor (CTCF) [73]. CTCF is an important methyl-sensitive regulator of transcription involved in the epigenetic regulation of genomic imprinted loci by influencing genomic 3D conformation [74]. Accordingly, the methylation status of IGF2-C $\mathrm{BI}_{\mathrm{BI}}$ correlates positively with the expression of $m i R-483-3 p$ [35]. There are no direct data about the influence of the methylation status of the ICR of the IGF2/H19 locus and the expression of the miR-483 gene yet. However, the paternal allele expression, ruled by the ICR methylation, should reasonably open the chromatin also for the $m i R-483$ gene expression.

\subsection{Other Mechanisms}

Recently it was shown that the pseudogene HMGA1P7 could up-regulates miR-483 through a competing endogenous RNA (ceRNA) mechanism that induces the Egr1 transcription factor, a positive regulator of $m i R-483$ expression [75]. 
It was also shown that the temperature could regulate the miR-483 locus, so, a mild hypothermia induces an increased expression of the miRNA [76]. Moreover, miR-483 may self-regulate its own expression independently of its host gene IGF2 in human HeLa cells by activating the USF1 transcription factor [77].

\section{Physiological Roles of MiR-483-3p}

MiR-483-3p influences many biological processes. Here summary of the most known is provided:

\subsection{Cell Cycle Regulation}

In a study on skin wound repair, it was observed that $m i R-483-3 p$ is accumulated in the terminal phase of the repair process and blocks the cell cycle of keratinocytes by targeting the phosphatase CDC25A. The $m i R-483-3 p$ silencing leads to a continuous proliferation and delays the differentiation [34,78].

\subsection{Melatonin Synthesis}

In the pineal gland, it was observed a decreased expression of $m i R-483-3 p$ during development, increasing of the $m i R-483-3 p$ target $A A N A T$, and melatonin synthesis [32].

\subsection{Adipocytes Differentiation and Imprinting in Newborns}

Administration of $m i R-483-3 p$ modulates the capacity of adipocytes to differentiate and store lipids in vitro. These effects are probably mediated by translational repression of the growth/differentiation factor-3 (GDF3), a target of $m i R-483-3 p$. In vivo observations registered that $m i R-483-3 p$ expression can be regulated by diet and can affect the development of the adipose tissues in off-springs. So, $m i R-483-3 p$ is up-regulated in adipose tissue from low-birth-weight adult humans and pre-diabetic adult rats exposed to suboptimal nutrition in early life. The authors proposed that increased $m i R-483-3 p$ expression causes lipotoxicity and insulin resistance by limiting storage of lipids in adipose tissue. In this view changes in miRNA expression during early-life nutrition could increase susceptibility to metabolic diseases affecting long-term health [79]. Finally, the authors observed, that in a cohort of 244 twins the environmental factors rather than genetics influence changes in $m i R-483-3 p$ expression [80].

The effect of the diet on $m i R-483-3 p$ regulation seems to act before birth. In mice, maternal high fat diet reduces the expression of a group of miRNAs in adult offspring liver, including the $m m u-m i R-483-3 p$ [81]. These data attest the importance of the environmental factors on $m i R-483-3 p$ regulation and their capacity to affect the cellular development and long-term health.

\subsection{Matrix Production in Eye Cells}

MiR-483-3p reduces the production of extracellular matrix (ECM) in Human Trabecular Meshwork Cells by targeting of SMAD4, and in turn reducing the activity of the TGF- $\beta$ pathway in the eye. This relationship between $m i R-483-3 p$ and the ECM production makes this microRNA a potential target to treat glaucoma [82].

\subsection{Vascular Homeostasis}

MiR-483-3p rules the vascular homeostasis controlling the components of the renin-angiotensin system by regulating four different genes of the renin-angiotensin system (RAS) [83]. Moreover, $m i R-483-3 p$ is upregulated in endothelial progenitor cells (EPC) from deep vein thrombosis (DVT) patients and targets the serum response factor (SRF) to decrease EPCs migration and tube development, concomitantly to the increased rate of the apoptotic cells. In a rat model of venous thrombosis, $m i R-483-3 p$ inhibition led to the improved ability of homing and thrombus resolution of EPCs [84]. 


\subsection{Mesodermal Differentiation}

As already mentioned, $m i R-483-3 p$ could play an important function in differentiation. Mesoderm cells showed enrichment of miR-483-3p that was identified as a pivotal regulator for the differentiation to progenitor subpopulations toward lineage specification. MiR-483-3p effect was partially mimicked by repression of its target PGAM1 gene [39].

\section{4. $M i R-483-3 p$ in Cancer}

\subsection{MiR-483-3p Is Often Deregulated in Cancer}

Since $m i R-483-3 p$ is involved in numerous physiological processes, it is not surprising to find altered expression of this miRNA in diseases. MiR-483-3p was observed overexpressed in all the cases of cirrhotic liver and Wilms' tumor studied [12]. Moreover, it was found upregulated in adrenocortical carcinoma [85,86], malignant mesothelioma [87], pancreatic ductal adenocarcinoma [41], and significantly overexpressed in large subsets of colorectal cancer [36], breast cancer and hepatocellular carcinoma [12]. Different authors observed that the miR-483-3p expression was increased in cancer cell lines from different tissues treated with chemicals with oncosuppressor activity or radiation. For example, miR-483-3p expression increased after treatment with cisplatin in ovarian cancer [40], selenium in adenocarcinoma [88], and 5-fluorouracil in HCC [61], or with radioactive stress in a lung cancer cell model [89]. Moreover, it was observed that lipotoxic substances in HepG2 cells induced deregulation of $m i R-483-3 p$ [90]. Interestingly, the overexpression of $m i R-483-3 p$ was associated with resistance to apoptosis and clone selection.

Colon organoid culture functionally confirmed the microRNA $m i R-483$ as a dominant driver oncogene at the IGF2 locus; overexpression of miR-483-3p but not IGF2 induced high-grade dysplasia of Apc-null organoids by increasing proliferation and invasion in vitro and tumorigenicity in vivo [11].

\subsection{MiR-483-3p and the TP53/MiR145-5p Loop in Liver Cancer}

Different mechanisms were proposed to explain how the $m i R-483-3 p$ overexpression could drive advantages to cancer. For example, an important study showed how miR-483-3p can modulate the immune response against cancer cells. It was reported that IGF1 and IGF2 suppress their expression each other and their concentration can affect the immune response. IGF1 promotes the development and cytotoxic activity of human NK cells [37], therefore the reduction of this protein by the augmented expression of IGF2 by miR-483-5p [91], or by the direct targeting of IGF1 by $m i R-483-3 p[92,93]$, provide a protection to cancer cells by suppressing NK cells activity.

Today, the most studied mechanism about how miR-483-3p could induce the chemoresistance in cancer cells involves the capacity of the miR to affect the pro-apoptotic TP53 signaling in the context of the liver cancer. In hepatocellular carcinoma (HCC), the expression of miR-483-3p is related to the mutational status of TP53, CTNNB1 genes and impaired epigenetic mechanisms affecting the IGF2/miR-483/H19 locus. Interesting, CTNNB1 and TP53 are the most commonly mutated gene HCC (in about the $50 \%$ of all cases), but mutations in these two genes are mutually excluding. Therefore, HCC tumors mutated in CTNNB1 seldom have mutations in TP53 [94]. Notably, IGF2, $\beta$-catenin and TP53 are related to cellular metabolism [95,96], and lipid and glucose metabolisms are impaired in HCC [97]. In this context, it was observed that the miR-483-3p acts as "onco-miR" targeting the pro-apoptotic gene TP53 Upregulated Modulator of Apoptosis protein (BBC3/PUMA) [12,35]. PUMA is one of the principal effectors of the TP53 apoptotic pathway, and reduction of PUMA can inhibit the apoptosis induced by the TP53 signaling activation. Therefore, miR-483-3p aberrant expression could be the elements that explain the mutual exclusion of the mutational status between CTNNB1 and TP53 in HCC. It was showed how mutations in CTNNB1, those permitting to escape the auto-regulation of the miR-483-3p, could lead to an accumulation of the protein and of $m i R-483-3 p$, blocking the pro-apoptotic activity of the TP53 pathway. In fact it was demonstrated that the 
overexpression of the miR-483-3p can overcome the miR-145-5p/TP53 axis in HepG2, and that the cellular glucose concentration has a major in the interplay between these factors [98].

MiR-145-5p induces p53-dependent apoptosis targeting MDM2 [99-104], an inhibitor of TP53 that induces its degradation by ubiquitination. Accordingly, miR-145-5p is generally down-regulated in several tumors, including hepatocellular carcinomas (HCCs) [105-110]. TP53 is a transcriptional activator of $m i R-145-5 p$, and it is also implicated in the microRNA maturation complex. This generates a positive pro-apoptotic feedback loop between miR-145-5p and TP53 [102,104,111,112]. However, notwithstanding the oncosupressor role of miR-145-5p, some HCC cases showed a physiological expression of this miRNA. Experiments on HepG2 cell line showed that ectopic constant activation of the TP53/miR-145-5p signaling induces apoptosis in almost all the cells, but additionally lead to the selection of clones that exhibit higher miR-483-3p expression. Depletion of miR-483-3p in these cells reinforces apoptosis, strengthening the concept that the overexpression of the miR-483-3p helps the cancer cells to overcome the programmed cell death. The glucose concentration has a critical role in the $m i R-483-3 p$ and $m i R-145-5 p$ connected functions. In liver cancer cells grown in low glucose conditions $m i R-145-5 p$ lowered $m i R-483-3 p$, allowing apoptosis. Instead, when cells were grown in high glucose, the levels of $m i R-483-3 p$ increased in response to $m i R-145-5 p$, reducing the apoptotic rate (Figure 3). Accordingly, $m i R-145-5 p$ and $m i R-483-3 p$ correlate negatively in the non-neoplastic livers, but positively in HCCs that have impaired glucose metabolism. This oncogenetic mechanism of the miR-483-3p could be common also in other types of tumors, but it has still to be directly proven. However, the connection between the TP53 pro-apoptotic pathway and miR-483-3p involves several factors that can have auto-regulative loops. For example, OGT activity was shown to upregulate $m i R-483-3 p$ expression, and to potentially have an oncogenic role in cancer by glucose uptake, but at the same time, was shown that inhibition of OGA, the enzyme that catalyzes O-GlcNAc hydrolysis, stabilizes TP53 from degradation in cancer [113].

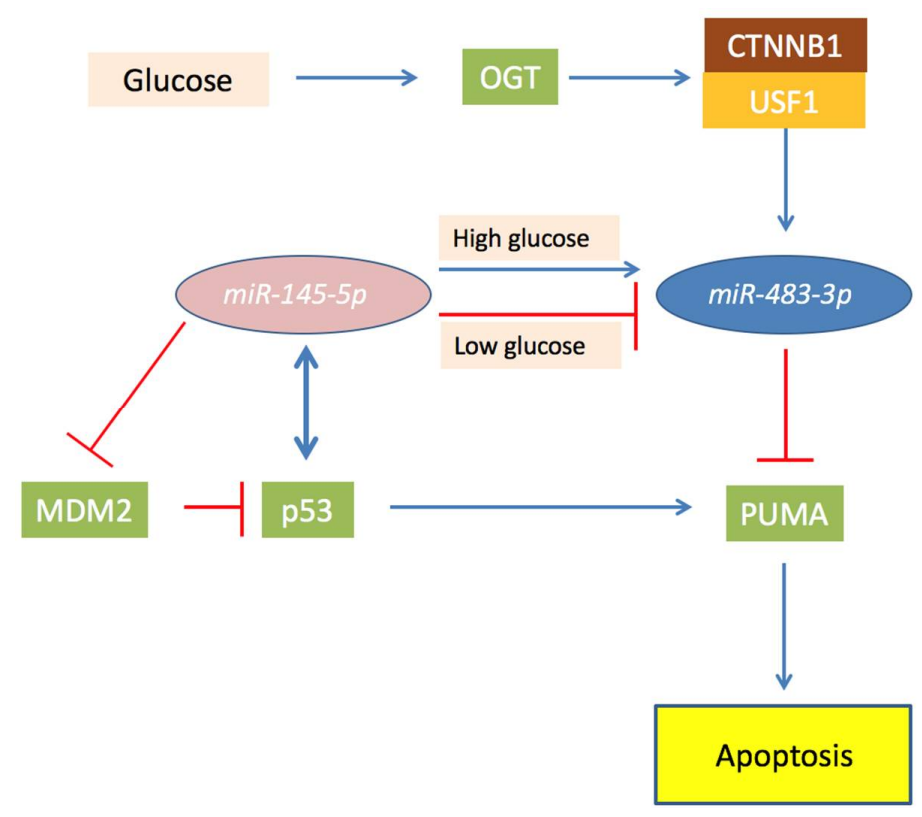

Figure 3. Schematic representation of the role of $O$-linked $\beta$ - $N$-acetylglucosamine transferase (OGT) and $m i R-483-3 p$ in the miR-145-5p/TP53 axis in hepatocellular carcinoma (HCC). In the Figure are showed proteins (squares) and miRNAs (ovals) and their functional connection involved in the $m i R-145-5 p /$ TP53 axis in HCC. Briefly, miR-145-5p targets MDM2 and reduces expression of miR-483-3p, permitting the activation of TP53 that induce PUMA and apoptosis. In case of OGT over-activity, $m i R-145-5 p$ is unable to regulate miR-483-3p which expression is increased by CTNNB1 activity. This leads the miR-483-3p to target PUMA and blocking the pro-apoptotic effect of TP53. 


\subsection{MiR-483-3p as Cancer Biomarker}

Some authors evaluated the possibility to use the $m i R-483-3 p$ as a biomarker for diagnosis and follow-up of cancer events [114]. MiR-483 was observed overexpressed in esophageal squamous cell carcinoma (ESCC) tissues, and its overexpression was negatively correlated with the prognosis and positively correlated with multidrug resistance. In vitro functional experiments showed that miR-483-3p could promote the proliferation, migration and could inhibit cells' sensitivity to chemotherapy drugs [115]. In patients with pancreatic ductal adenocarcinoma (PDAC) it was observed a high expression, relative to healthy controls of the $m i R-483-3 p$ and $m i R-21$ in blood samples [116]. Moreover, some articles suggest that aberrant $m i R-483-3 p$ expression is an early event in PDAC tumorigenesis and that is associated with tumor differentiation and prognosis, indicating $m i R-483-3 p$ also as a potential therapeutic target for PDAC [117]. In addition, $m i R-483-3 p$ overexpression in plasma from patients with adrenal cortical cancer and pancreatic ductal adenocarcinoma improved the diagnostic accuracy of these diseases $[86,116]$, and some authors suggest the efficacy of the miR-483-3p as biomarker in prostate cancer as well [118]. In another study on colorectal cancer, was observed that in tumor tissues the expression of both miR-483-3p/-5p and IGF2 was significantly up-regulated in more than $60 \%$ of cases with a concomitant positive correlation between the two genes. However, only miR-483-5p showed high levels in serum, useful as sensitivity biomarker for the CRC [36]. The miR-483-5p was found significantly up-regulated in the serum of a broad range of cancer and pathological conditions ascribing it as potential cancer biomarker [11,13,15,119-124].

\subsection{Oncosuppressor Role of MiR 483-3p}

Not all the observations in literature concord that $m i R-483-3 p$ acts as an oncomiR. It was observed that the miR-483-3p expression is decreased in gastric, nasopharyngeal, and some cases of hepatocellular carcinomas [125-128]. MiR-483-3p sensitized squamous cell carcinoma cells to drug-induced apoptosis by the direct targeting of several anti-apoptotic genes, such as API5, BIRC5, and RAN [78]. In a microarray analysis of breast cancer samples, was observed that the miR-483-3p and $m i R-483-5 p$ are significantly deregulated, and the authors underline that these miRNAs could have a key role during the initiation and the progression of the disease [129].

In the context of liver cancer, it was shown that $m i R-483-3 p$ and $483-5 p$ are down-regulated in hepatitis B virus-associated HCCs [127]. Overexpression of $m i R-483-3 p$ and $-5 p$ reduced liver fibrosis in murine model [130] In a study involving 18 HCC samples, the microRNAs $483-3 p$ and $-5 p$ were observed down-regulated in tumors [126]; miR-483-3p down-regulated in alcoholic hepatitis and in DDC (Diethyl 1,4-dehydro-2,4,6-trimethyl-3,5-pyridine-dicarboxylate) re-fed mice livers [33]. However, these studies do not consider the mutational status of the TP53 or CTNNB1 genes.

\section{Discussion}

In this work, we focused on $m i R-483-3 p$ roles in cancer. It has been found involved in several aspects of the cellular homeostasis, and its ability to link crucial cellular pathways such as TP53, TGF $\beta, W n t / \beta$-catenin and metabolic signaling give to it a large impact on the regulation of neoplastic cells. Indeed, this short non-coding RNA exemplifies the exceptional role of the microRNAs linking epigenetics, metabolism, microenvironment, programmed cell death and cellular differentiation. Consequently, considering $m i R-483-3 p$ as oncosuppressor or oncogene is challenging. However, in most of the cases reported in the literature, the overexpression of miR-483-3p is positively associated to cancer. There is another critical microRNA cancer-related that resemblance the miR-483-3p, miR-221. $H s a-m i R-221$ is up-regulated in several types of cancer, directly induced by TP53 and able to targets several downstream effectors of the TP53 pathway as BBC3/PUMA, BMF, PTEN and MDM2 [131-134]. Therefore, the ability to downregulate downstream effectors of the TP53 pathway by microRNAs that in turn are regulated by TP53 seems to be a common feature at least in those tumors where these microRNAs are de-regulated. 
For all these reasons the $m i R-483-3 p$ represents a promising cancer therapeutic target. However, it is involved in pathways that are ruled by reversible changes that in turn control cellular plasticity. Since cancer cells exploit cellular plasticity to environmental adaptation and tumor progression [135], all the genetic, epigenetic and metabolic aspects related to $m i R-483-3 p$ have to be unveiled in order to reach a productive targeting of this microRNA in an anti-cancer therapeutic view.

Author Contributions: F.P., R.V. and A.V. wrote the review.

Funding: This work was supported by the Italian Ministry of Health (GR-2011-02350699).

Conflicts of Interest: The authors declare no conflict of interest.

\section{References}

1. Ambros, V. The functions of animal microRNAs. Nature 2004, 431, 350-355. [CrossRef] [PubMed]

2. Calin, G.A.; Croce, C.M. MicroRNA signatures in human cancers. Nat. Rev. Cancer 2006, 6, 857-866. [CrossRef] [PubMed]

3. Iorio, M.V.; Croce, C.M. MicroRNAs in cancer: Small molecules with a huge impact. J. Clin. Oncol. 2009, 27, 5848-5856. [CrossRef] [PubMed]

4. Negrini, M.; Ferracin, M.; Sabbioni, S.; Croce, C.M. MicroRNAs in human cancer: From research to therapy. J. Cell Sci. 2007, 120, 1833-1840. [CrossRef] [PubMed]

5. Fu, H.; Tie, Y.; Xu, C.; Zhang, Z.; Zhu, J.; Shi, Y.; Jiang, H.; Sun, Z.; Zheng, X. Identification of human fetal liver miRNAs by a novel method. FEBS Lett. 2005, 579, 3849-3854. [CrossRef] [PubMed]

6. Lapunzina, P. Risk of tumorigenesis in overgrowth syndromes: A comprehensive review. Am. J. Med. Genet. C Semin. Med. Genet. 2005, 137C, 53-71. [CrossRef] [PubMed]

7. Livingstone, C. Igf2 and cancer. Endocr. Relat. Cancer 2013, 20, R321-R339. [CrossRef] [PubMed]

8. Rainier, S.; Johnson, L.A.; Dobry, C.J.; Ping, A.J.; Grundy, P.E.; Feinberg, A.P. Relaxation of imprinted genes in human cancer. Nature 1993, 362, 747-749. [CrossRef] [PubMed]

9. Sun, F.L.; Dean, W.L.; Kelsey, G.; Allen, N.D.; Reik, W. Transactivation of IGF2 in a mouse model of beckwith-wiedemann syndrome. Nature 1997, 389, 809-815. [PubMed]

10. Cancer Genome Atlas, N. Comprehensive molecular characterization of human colon and rectal cancer. Nature 2012, 487, 330-337. [CrossRef] [PubMed]

11. Li, X.; Nadauld, L.; Ootani, A.; Corney, D.C.; Pai, R.K.; Gevaert, O.; Cantrell, M.A.; Rack, P.G.; Neal, J.T.; Chan, C.W.; et al. Oncogenic transformation of diverse gastrointestinal tissues in primary organoid culture. Nat. Med. 2014, 20, 769-777. [CrossRef] [PubMed]

12. Veronese, A.; Lupini, L.; Consiglio, J.; Visone, R.; Ferracin, M.; Fornari, F.; Zanesi, N.; Alder, H.; D’Elia, G.; Gramantieri, L.; et al. Oncogenic role of miR-483-3p at the IGF2/483 locus. Cancer Res. 2010, 70, 3140-3149. [CrossRef] [PubMed]

13. Perge, P.; Butz, H.; Pezzani, R.; Bancos, I.; Nagy, Z.; Paloczi, K.; Nyiro, G.; Decmann, A.; Pap, E.; Luconi, M.; et al. Evaluation and diagnostic potential of circulating extracellular vesicle-associated microRNAs in adrenocortical tumors. Sci. Rep. 2017, 7, 5474. [CrossRef] [PubMed]

14. Dai, X.; Pang, W.; Zhou, Y.; Yao, W.; Xia, L.; Wang, C.; Chen, X.; Zen, K.; Zhang, C.Y.; Yuan, Y. Altered profile of serum microRNAs in pancreatic cancer-associated new-onset diabetes mellitus. J. Diabetes 2016, 8, 422-433. [CrossRef] [PubMed]

15. Zhu, Y.; Peng, Q.; Lin, Y.; Zou, L.; Shen, P.; Chen, F.; Min, M.; Shen, L.; Chen, J.; Shen, B. Identification of biomarker microRNAs for predicting the response of colorectal cancer to neoadjuvant chemoradiotherapy based on microRNA regulatory network. Oncotarget 2017, 8, 2233-2248. [CrossRef] [PubMed]

16. Luan, J.; Wang, J.; Su, Q.; Chen, X.; Jiang, G.; Xu, X. Meta-analysis of the differentially expressed microRNA profiles in nasopharyngeal carcinoma. Oncotarget 2016, 7, 10513-10521. [CrossRef] [PubMed]

17. Zheng, X.H.; Cui, C.; Ruan, H.L.; Xue, W.Q.; Zhang, S.D.; Hu, Y.Z.; Zhou, X.X.; Jia, W.H. Plasma microRNA profiling in nasopharyngeal carcinoma patients reveals $m i R-548 q$ and $m i R-483-5 p$ as potential biomarkers. Chin. J. Cancer 2014, 33, 330-338. [PubMed]

18. Wang, M.; Wen, T.F.; He, L.H.; Li, C.; Zhu, W.J.; Trishul, N.M. A six-microRNA set as prognostic indicators for bile duct cancer. Int. J. Clin. Exp. Med. 2015, 8, 17261-17270. [PubMed] 
19. Song, Q.; Xu, Y.; Yang, C.; Chen, Z.; Jia, C.; Chen, J.; Zhang, Y.; Lai, P.; Fan, X.; Zhou, X.; et al. MiR-483-5p promotes invasion and metastasis of lung adenocarcinoma by targeting RHOGDI1 and ALCAM. Cancer Res. 2014, 74, 3031-3042. [CrossRef] [PubMed]

20. Xu, H.; Yang, Y.; Zhao, H.; Yang, X.; Luo, Y.; Ren, Y.; Liu, W.; Li, N. Serum miR-483-5p: A novel diagnostic and prognostic biomarker for patients with oral squamous cell carcinoma. Tumour Biol. 2016, 37, 447-453. [CrossRef] [PubMed]

21. Nagamitsu, Y.; Nishi, H.; Sasaki, T.; Takaesu, Y.; Terauchi, F.; Isaka, K. Profiling analysis of circulating microRNA expression in cervical cancer. Mol. Clin. Oncol. 2016, 5, 189-194. [CrossRef] [PubMed]

22. Meyer-Rochow, G.Y.; Jackson, N.E.; Conaglen, J.V.; Whittle, D.E.; Kunnimalaiyaan, M.; Chen, H.; Westin, G.; Sandgren, J.; Stalberg, P.; Khanafshar, E.; et al. MicroRNA profiling of benign and malignant pheochromocytomas identifies novel diagnostic and therapeutic targets. Endocr. Relat. Cancer 2010, 17, 835-846. [CrossRef] [PubMed]

23. Patterson, E.E.; Holloway, A.K.; Weng, J.; Fojo, T.; Kebebew, E. MicroRNA profiling of adrenocortical tumors reveals miR-483 as a marker of malignancy. Cancer 2011, 117, 1630-1639. [CrossRef] [PubMed]

24. Yu, X.; Zhang, X.; Bi, T.; Ding, Y.; Zhao, J.; Wang, C.; Jia, T.; Han, D.; Guo, G.; Wang, B.; et al. MiRNA expression signature for potentially predicting the prognosis of ovarian serous carcinoma. Tumour Biol. 2013, 34, 3501-3508. [CrossRef] [PubMed]

25. Zuntini, M.; Salvatore, M.; Pedrini, E.; Parra, A.; Sgariglia, F.; Magrelli, A.; Taruscio, D.; Sangiorgi, L. MicroRNA profiling of multiple osteochondromas: Identification of disease-specific and normal cartilage signatures. Clin. Genet. 2010, 78, 507-516. [CrossRef] [PubMed]

26. Wang, H.Y.; Yan, L.X.; Shao, Q.; Fu, S.; Zhang, Z.C.; Ye, W.; Zeng, Y.X.; Shao, J.Y. Profiling plasma microRNA in nasopharyngeal carcinoma with deep sequencing. Clin. Chem. 2014, 60, 773-782. [CrossRef] [PubMed]

27. Kozomara, A.; Griffiths-Jones, S. Mirbase: Annotating high confidence microRNAs using deep sequencing data. Nucleic Acids Res. 2014, 42, D68-D73. [CrossRef] [PubMed]

28. Kozomara, A.; Griffiths-Jones, S. Mirbase: Integrating microRNA annotation and deep-sequencing data. Nucleic Acids Res. 2011, 39, D152-D157. [CrossRef] [PubMed]

29. Griffiths-Jones, S.; Saini, H.K.; van Dongen, S.; Enright, A.J. Mirbase: Tools for microRNA genomics. Nucleic Acids Res. 2008, 36, D154-D158. [CrossRef] [PubMed]

30. Griffiths-Jones, S.; Grocock, R.J.; van Dongen, S.; Bateman, A.; Enright, A.J. Mirbase: MicroRNA sequences, targets and gene nomenclature. Nucleic Acids Res. 2006, 34, D140-D144. [CrossRef] [PubMed]

31. Griffiths-Jones, S. The microRNA registry. Nucleic Acids Res. 2004, 32, D109-D111. [CrossRef] [PubMed]

32. Clokie, S.J.; Lau, P.; Kim, H.H.; Coon, S.L.; Klein, D.C. MicroRNAs in the pineal gland: MiR-483 regulates melatonin synthesis by targeting arylalkylamine $N$-acetyltransferase. J. Biol. Chem. 2012, 287, 25312-25324. [CrossRef] [PubMed]

33. Liu, H.; French, B.A.; Li, J.; Tillman, B.; French, S.W. Altered regulation of miR-34a and miR-483-3p in alcoholic hepatitis and ddc fed mice. Exp. Mol. Pathol. 2015, 99, 552-557. [CrossRef] [PubMed]

34. Bertero, T.; Gastaldi, C.; Bourget-Ponzio, I.; Mari, B.; Meneguzzi, G.; Barbry, P.; Ponzio, G.; Rezzonico, R. Cdc25a targeting by $m i R-483-3 p$ decreases ccnd-cdk4/6 assembly and contributes to cell cycle arrest. Cell Death Differ. 2013, 20, 800-811. [CrossRef] [PubMed]

35. Veronese, A.; Visone, R.; Consiglio, J.; Acunzo, M.; Lupini, L.; Kim, T.; Ferracin, M.; Lovat, F.; Miotto, E.; Balatti, V.; et al. Mutated beta-catenin evades a microRNA-dependent regulatory loop. Proc. Natl. Acad. Sci. USA 2011, 108, 4840-4845. [CrossRef] [PubMed]

36. Cui, H.; Liu, Y.; Jiang, J.; Liu, Y.; Yang, Z.; Wu, S.; Cao, W.; Cui, I.H.; Yu, C. Igf2-derived miR-483 mediated oncofunction by suppressing dlc-1 and associated with colorectal cancer. Oncotarget 2016, 7, 48456. [CrossRef] [PubMed]

37. Ni, F.; Sun, R.; Fu, B.; Wang, F.; Guo, C.; Tian, Z.; Wei, H. IGF-1 promotes the development and cytotoxic activity of human nk cells. Nat. Commun. 2013, 4, 1479. [CrossRef] [PubMed]

38. Bertero, T.; Gastaldi, C.; Bourget-Ponzio, I.; Imbert, V.; Loubat, A.; Selva, E.; Busca, R.; Mari, B.; Hofman, P.; Barbry, P.; et al. MiR-483-3p controls proliferation in wounded epithelial cells. FASEB J. 2011, 25, 3092-3105. [CrossRef] [PubMed]

39. Ishikawa, D.; Diekmann, U.; Fiedler, J.; Just, A.; Thum, T.; Lenzen, S.; Naujok, O. Mirnome profiling of purified endoderm and mesoderm differentiated from hescs reveals functions of $m i R-483-3 p$ and $m i R-1263$ for cell-fate decisions. Stem Cell Rep. 2017, 9, 1588-1603. [CrossRef] [PubMed] 
40. Arrighetti, N.; Cossa, G.; De Cecco, L.; Stucchi, S.; Carenini, N.; Corna, E.; Gandellini, P.; Zaffaroni, N.; Perego, P.; Gatti, L. Pkc-alpha modulation by miR-483-3p in platinum-resistant ovarian carcinoma cells. Toxicol. Appl. Pharmacol. 2016, 310, 9-19. [CrossRef] [PubMed]

41. Hao, J.; Zhang, S.; Zhou, Y.; Hu, X.; Shao, C. MicroRNA 483-3p suppresses the expression of DPC4/Smad4 in pancreatic cancer. FEBS Lett. 2011, 585, 207-213. [CrossRef] [PubMed]

42. Fearon, E.R.; Vogelstein, B.; Feinberg, A.P. Somatic deletion and duplication of genes on chromosome 11 in wilms' tumours. Nature 1984, 309, 176-178. [CrossRef] [PubMed]

43. Ali, I.U.; Lidereau, R.; Theillet, C.; Callahan, R. Reduction to homozygosity of genes on chromosome 11 in human breast neoplasia. Science 1987, 238, 185-188. [CrossRef] [PubMed]

44. Fearon, E.R.; Feinberg, A.P.; Hamilton, S.H.; Vogelstein, B. Loss of genes on the short arm of chromosome 11 in bladder cancer. Nature 1985, 318, 377-380. [CrossRef] [PubMed]

45. Weston, A.; Willey, J.C.; Modali, R.; Sugimura, H.; McDowell, E.M.; Resau, J.; Light, B.; Haugen, A.; Mann, D.L.; Trump, B.F.; et al. Differential DNA sequence deletions from chromosomes 3, 11, 13, and 17 in squamous-cell carcinoma, large-cell carcinoma, and adenocarcinoma of the human lung. Proc. Natl. Acad. Sci. USA 1989, 86, 5099-5103. [CrossRef] [PubMed]

46. Lee, J.H.; Kavanagh, J.J.; Wharton, J.T.; Wildrick, D.M.; Blick, M. Allele loss at the c-Ha-ras1 locus in human ovarian cancer. Cancer Res. 1989, 49, 1220-1222. [PubMed]

47. Kurukuti, S.; Tiwari, V.K.; Tavoosidana, G.; Pugacheva, E.; Murrell, A.; Zhao, Z.; Lobanenkov, V.; Reik, W.; Ohlsson, R. CTCF binding at the $\mathrm{H} 19$ imprinting control region mediates maternally inherited higher-order chromatin conformation to restrict enhancer access to IGF2. Proc. Natl. Acad. Sci. USA 2006, 103, 10684-10689. [CrossRef] [PubMed]

48. Reeve, A.E.; Eccles, M.R.; Wilkins, R.J.; Bell, G.I.; Millow, L.J. Expression of insulin-like growth factor-II transcripts in wilms' tumour. Nature 1985, 317, 258-260. [CrossRef] [PubMed]

49. Poirier, K.; Chalas, C.; Tissier, F.; Couvert, P.; Mallet, V.; Carrie, A.; Marchio, A.; Sarli, D.; Gicquel, C.; Chaussade, S.; et al. Loss of parental-specific methylation at the IGF2 locus in human hepatocellular carcinoma. J. Pathol. 2003, 201, 473-479. [CrossRef] [PubMed]

50. Leick, M.B.; Shoff, C.J.; Wang, E.C.; Congress, J.L.; Gallicano, G.I. Loss of imprinting of IGF2 and the epigenetic progenitor model of cancer. Am. J. Stem Cells 2012, 1, 59-74. [PubMed]

51. Yoshimizu, T.; Miroglio, A.; Ripoche, M.A.; Gabory, A.; Vernucci, M.; Riccio, A.; Colnot, S.; Godard, C.; Terris, B.; Jammes, H.; et al. The H19 locus acts in vivo as a tumor suppressor. Proc. Natl. Acad. Sci. USA 2008, 105, 12417-12422. [CrossRef] [PubMed]

52. Hu, Q.; Gao, F.; Tian, W.; Ruteshouser, E.C.; Wang, Y.; Lazar, A.; Stewart, J.; Strong, L.C.; Behringer, R.R.; Huff, V. Wt1 ablation and IGF2 upregulation in mice result in wilms tumors with elevated ERK1/2 phosphorylation. J. Clin. Investig. 2011, 121, 174-183. [CrossRef] [PubMed]

53. Nusse, R. Cancer. Converging on beta-catenin in wilms tumor. Science 2007, 316, 988-989. [CrossRef] [PubMed]

54. Reya, T.; Clevers, H. Wnt signalling in stem cells and cancer. Nature 2005, 434, 843-850. [CrossRef] [PubMed]

55. De La Coste, A.; Romagnolo, B.; Billuart, P.; Renard, C.A.; Buendia, M.A.; Soubrane, O.; Fabre, M.; Chelly, J.; Beldjord, C.; Kahn, A.; et al. Somatic mutations of the beta-catenin gene are frequent in mouse and human hepatocellular carcinomas. Proc. Natl. Acad. Sci. USA 1998, 95, 8847-8851. [CrossRef] [PubMed]

56. Kahn, A. Transcriptional regulation by glucose in the liver. Biochimie 1997, 79, 113-118. [CrossRef]

57. Corre, S.; Galibert, M.D. Upstream stimulating factors: Highly versatile stress-responsive transcription factors. Pigment. Cell Res. 2005, 18, 337-348. [CrossRef] [PubMed]

58. Cognard, E.; Dargaville, C.G.; Hay, D.L.; Shepherd, P.R. Identification of a pathway by which glucose regulates beta-catenin signalling via the camp/protein kinase a pathway in beta-cell models. Biochem. J. 2013, 449, 803-811. [CrossRef] [PubMed]

59. Dynkevich, Y.; Rother, K.I.; Whitford, I.; Qureshi, S.; Galiveeti, S.; Szulc, A.L.; Danoff, A.; Breen, T.L.; Kaviani, N.; Shanik, M.H.; et al. Tumors, IGF-2, and hypoglycemia: Insights from the clinic, the laboratory, and the historical archive. Endocr. Rev. 2013, 34, 798-826. [CrossRef] [PubMed]

60. Qiao, Y.; Zhao, Y.; Liu, Y.; Ma, N.; Wang, C.; Zou, J.; Liu, Z.; Zhou, Z.; Han, D.; He, J.; et al. MiR-483-3p regulates hyperglycaemia-induced cardiomyocyte apoptosis in transgenic mice. Biochem. Biophys. Res. Commun. 2016, 477, 541-547. [CrossRef] [PubMed] 
61. Pepe, F.; Pagotto, S.; Soliman, S.; Rossi, C.; Lanuti, P.; Braconi, C.; Mariani-Costantini, R.; Visone, R.; Veronese, A. Regulation of $m i R-483-3 p$ by the $O$-linked $N$-acetylglucosamine transferase links chemosensitivity to glucose metabolism in liver cancer cells. Oncogenesis 2017, 6, e328. [CrossRef] [PubMed]

62. Slawson, C.; Housley, M.P.; Hart, G.W. O-glcnac cycling: How a single sugar post-translational modification is changing the way we think about signaling networks. J. Cell. Biochem. 2006, 97, 71-83. [CrossRef] [PubMed]

63. Hart, G.W.; Housley, M.P.; Slawson, C. Cycling of o-linked beta-N-acetylglucosamine on nucleocytoplasmic proteins. Nature 2007, 446, 1017-1022. [CrossRef] [PubMed]

64. Chen, Q.; Chen, Y.; Bian, C.; Fujiki, R.; Yu, X. Tet2 promotes histone O-glcnacylation during gene transcription. Nature 2013, 493, 561-564. [CrossRef] [PubMed]

65. Yang, X.; Ongusaha, P.P.; Miles, P.D.; Havstad, J.C.; Zhang, F.; So, W.V.; Kudlow, J.E.; Michell, R.H.; Olefsky, J.M.; Field, S.J.; et al. Phosphoinositide signalling links $\mathrm{O}$-glcnac transferase to insulin resistance. Nature 2008, 451, 964-969. [CrossRef] [PubMed]

66. Olivier-Van Stichelen, S.; Guinez, C.; Mir, A.M.; Perez-Cervera, Y.; Liu, C.; Michalski, J.C.; Lefebvre, T. The hexosamine biosynthetic pathway and $O$-glcnacylation drive the expression of beta-catenin and cell proliferation. Am. J. Phys. Endocrinol. Metab. 2012, 302, E417-E424. [CrossRef] [PubMed]

67. Olivier-Van Stichelen, S.; Dehennaut, V.; Buzy, A.; Zachayus, J.L.; Guinez, C.; Mir, A.M.; El Yazidi-Belkoura, I.; Copin, M.C.; Boureme, D.; Loyaux, D.; et al. O-glcnacylation stabilizes beta-catenin through direct competition with phosphorylation at threonine 41. FASEB J. 2014, 28, 3325-3338. [CrossRef] [PubMed]

68. Shafi, R.; Iyer, S.P.; Ellies, L.G.; O’Donnell, N.; Marek, K.W.; Chui, D.; Hart, G.W.; Marth, J.D. The O-glcnac transferase gene resides on the $\mathrm{X}$ chromosome and is essential for embryonic stem cell viability and mouse ontogeny. Proc. Natl. Acad. Sci. USA 2000, 97, 5735-5739. [CrossRef] [PubMed]

69. Onodera, Y.; Nam, J.M.; Bissell, M.J. Increased sugar uptake promotes oncogenesis via EPAC/RAP1 and O-glcnac pathways. J. Clin. Investig. 2014, 124, 367-384. [CrossRef] [PubMed]

70. Butkinaree, C.; Park, K.; Hart, G.W. O-linked beta-N-acetylglucosamine (O-glcnac): Extensive crosstalk with phosphorylation to regulate signaling and transcription in response to nutrients and stress. Biochim. Biophys. Acta 2010, 1800, 96-106. [CrossRef] [PubMed]

71. Comer, F.I.; Hart, G.W. Reciprocity between O-glcnac and O-phosphate on the carboxyl terminal domain of RNA polymerase ii. Biochemistry 2001, 40, 7845-7852. [CrossRef] [PubMed]

72. Buren, S.; Gomes, A.L.; Teijeiro, A.; Fawal, M.A.; Yilmaz, M.; Tummala, K.S.; Perez, M.; Rodriguez-Justo, M.; Campos-Olivas, R.; Megias, D.; et al. Regulation of OGT by URI in response to glucose confers c-MYC-dependent survival mechanisms. Cancer Cell 2016, 30, 290-307. [CrossRef] [PubMed]

73. Du, M.; Beatty, L.G.; Zhou, W.; Lew, J.; Schoenherr, C.; Weksberg, R.; Sadowski, P.D. Insulator and silencer sequences in the imprinted region of human chromosome 11p15.5. Hum. Mol. Genet. 2003, 12, 1927-1939. [CrossRef] [PubMed]

74. Wang, H.; Maurano, M.T.; Qu, H.; Varley, K.E.; Gertz, J.; Pauli, F.; Lee, K.; Canfield, T.; Weaver, M.; Sandstrom, R.; et al. Widespread plasticity in CTCF occupancy linked to DNA methylation. Genome. Res. 2012, 22, 1680-1688. [CrossRef] [PubMed]

75. De Martino, M.; Palma, G.; Azzariti, A.; Arra, C.; Fusco, A.; Esposito, F. The hmga1 pseudogene 7 induces miR-483 and miR-675 upregulation by activating EGR1 through a cerna mechanism. Genes (Basel) 2017, 8, 330. [CrossRef] [PubMed]

76. Emmerling, V.V.; Fischer, S.; Stiefel, F.; Holzmann, K.; Handrick, R.; Hesse, F.; Horer, M.; Kochanek, S.; Otte, K. Temperature-sensitive miR-483 is a conserved regulator of recombinant protein and viral vector production in mammalian cells. Biotechnol. Bioeng. 2016, 113, 830-841. [CrossRef] [PubMed]

77. Emmerling, V.V.; Fischer, S.; Kleemann, M.; Handrick, R.; Kochanek, S.; Otte, K. MiR-483 is a self-regulating microRNA and can activate its own expression via USF1 in hela cells. Int. J. Biochem. Cell Biol. 2016, 80, 81-86. [CrossRef] [PubMed]

78. Bertero, T.; Bourget-Ponzio, I.; Puissant, A.; Loubat, A.; Mari, B.; Meneguzzi, G.; Auberger, P.; Barbry, P.; Ponzio, G.; Rezzonico, R. Tumor suppressor function of miR-483-3p on squamous cell carcinomas due to its pro-apoptotic properties. Cell Cycle 2013, 12, 2183-2193. [CrossRef] [PubMed] 
79. Ferland-McCollough, D.; Fernandez-Twinn, D.S.; Cannell, I.G.; David, H.; Warner, M.; Vaag, A.A.; Bork-Jensen, J.; Brons, C.; Gant, T.W.; Willis, A.E.; et al. Programming of adipose tissue miR-483-3p and gdf-3 expression by maternal diet in type 2 diabetes. Cell Death Differ. 2012, 19, 1003-1012. [CrossRef] [PubMed]

80. Bork-Jensen, J.; Thuesen, A.C.; Bang-Bertelsen, C.H.; Grunnet, L.G.; Pociot, F.; Beck-Nielsen, H.; Ozanne, S.E.; Poulsen, P.; Vaag, A. Genetic versus non-genetic regulation of miR-103, miR-143 and miR-483-3p expression in adipose tissue and their metabolic implications-a twin study. Genes 2014, 5, 508-517. [CrossRef] [PubMed]

81. Zhang, J.; Zhang, F.; Didelot, X.; Bruce, K.D.; Cagampang, F.R.; Vatish, M.; Hanson, M.; Lehnert, H.; Ceriello, A.; Byrne, C.D. Maternal high fat diet during pregnancy and lactation alters hepatic expression of insulin like growth factor-2 and key microRNAs in the adult offspring. BMC Genom. 2009, 10, 478. [CrossRef] [PubMed]

82. Shen, W.; Han, Y.; Huang, B.; Qi, Y.; Xu, L.; Guo, R.; Wang, X.; Wang, J. MicroRNA-483-3p inhibits extracellular matrix production by targeting smad4 in human trabecular meshwork cells. Investig. Ophthalmol. Vis. Sci. 2015, 56, 8419-8427. [CrossRef] [PubMed]

83. Kemp, J.R.; Unal, H.; Desnoyer, R.; Yue, H.; Bhatnagar, A.; Karnik, S.S. Angiotensin ii-regulated microRNA 483-3p directly targets multiple components of the renin-angiotensin system. J. Mol. Cell. Cardiol. 2014, 75, 25-39. [CrossRef] [PubMed]

84. Kong, L.; Hu, N.; Du, X.; Wang, W.; Chen, H.; Li, W.; Wei, S.; Zhuang, H.; Li, X.; Li, C. Upregulation of $m i R-483-3 p$ contributes to endothelial progenitor cells dysfunction in deep vein thrombosis patients via SRF. J. Transl. Med. 2016, 14, 23. [CrossRef] [PubMed]

85. Koperski, L.; Kotlarek, M.; Swierniak, M.; Kolanowska, M.; Kubiak, A.; Gornicka, B.; Jazdzewski, K.; Wojcicka, A. Next-generation sequencing reveals microRNA markers of adrenocortical tumors malignancy. Oncotarget 2017, 8, 49191-49200. [CrossRef] [PubMed]

86. Wang, C.; Sun, Y.; Wu, H.; Zhao, D.; Chen, J. Distinguishing adrenal cortical carcinomas and adenomas: A study of clinicopathological features and biomarkers. Histopathology 2014, 64, 567-576. [CrossRef] [PubMed]

87. Guled, M.; Lahti, L.; Lindholm, P.M.; Salmenkivi, K.; Bagwan, I.; Nicholson, A.G.; Knuutila, S. CDKN2A, NF2, and JUN are dysregulated among other genes by miRNAs in malignant mesothelioma-A miRNA microarray analysis. Genes Chromosomes Cancer 2009, 48, 615-623. [CrossRef] [PubMed]

88. McCann, M.J.; Rotjanapun, K.; Hesketh, J.E.; Roy, N.C. Expression profiling indicating low selenium-sensitive microRNA levels linked to cell cycle and cell stress response pathways in the CARO-2 cell line. Br. J. Nutr. 2017, 117, 1212-1221. [CrossRef] [PubMed]

89. Cui, F.M.; Li, J.X.; Chen, Q.; Du, H.B.; Zhang, S.Y.; Nie, J.H.; Cao, J.P.; Zhou, P.K.; Hei, T.K.; Tong, J. Radon-induced alterations in micro-RNA expression profiles in transformed BEAS2B cells. J. Toxicol. Environ. Health Part A 2013, 76, 107-119. [CrossRef] [PubMed]

90. Di Mauro, S.; Ragusa, M.; Urbano, F.; Filippello, A.; Di Pino, A.; Scamporrino, A.; Pulvirenti, A.; Ferro, A.; Rabuazzo, A.M.; Purrello, M.; et al. Intracellular and extracellular mirnome deregulation in cellular models of NAFLD or NASH: Clinical implications. Nutr. Metab. Cardiovasc. Dis. 2016, 26, 1129-1139. [CrossRef] [PubMed]

91. Tang, S.; Chen, Y.; Feng, S.; Yi, T.; Liu, X.; Li, Q.; Liu, Z.; Zhu, C.; Hu, J.; Yu, X.; et al. MiR-483-5p promotes igf-II transcription and is associated with poor prognosis of hepatocellular carcinoma. Oncotarget 2017, 8, 99871-99888. [CrossRef] [PubMed]

92. Sun, H.; Cai, J.; Xu, L.; Liu, J.; Chen, M.; Zheng, M.; Wang, L.; Yang, X. MiR-483-3p regulates acute myocardial infarction by transcriptionally repressing insulin growth factor 1 expression. Mol. Med. Rep. 2018, 17, 4785-4790. [CrossRef] [PubMed]

93. Vlachos, I.S.; Paraskevopoulou, M.D.; Karagkouni, D.; Georgakilas, G.; Vergoulis, T.; Kanellos, I.; Anastasopoulos, I.L.; Maniou, S.; Karathanou, K.; Kalfakakou, D.; et al. Diana-tarbase v7.0: Indexing more than half a million experimentally supported miRNA: mRNA interactions. Nucleic Acids Res. 2015, 43, D153-D159. [CrossRef] [PubMed]

94. Guichard, C.; Amaddeo, G.; Imbeaud, S.; Ladeiro, Y.; Pelletier, L.; Maad, I.B.; Calderaro, J.; Bioulac-Sage, P.; Letexier, M.; Degos, F.; et al. Integrated analysis of somatic mutations and focal copy-number changes identifies key genes and pathways in hepatocellular carcinoma. Nat. Genet. 2012, 44, 694-698. [CrossRef] [PubMed] 
95. Huang, Q.; Li, J.; Xing, J.; Li, W.; Li, H.; Ke, X.; Zhang, J.; Ren, T.; Shang, Y.; Yang, H.; et al. Cd147 promotes reprogramming of glucose metabolism and cell proliferation in HCC cells by inhibiting the p53-dependent signaling pathway. J. Hepatol. 2014, 61, 859-866. [CrossRef] [PubMed]

96. Chafey, P.; Finzi, L.; Boisgard, R.; Cauzac, M.; Clary, G.; Broussard, C.; Pegorier, J.P.; Guillonneau, F.; Mayeux, P.; Camoin, L.; et al. Proteomic analysis of beta-catenin activation in mouse liver by dige analysis identifies glucose metabolism as a new target of the wnt pathway. Proteomics 2009, 9, 3889-3900. [CrossRef] [PubMed]

97. Michelotti, G.A.; Machado, M.V.; Diehl, A.M. NAFLD, NASH and liver cancer. Nat. Rev. Gastroenterol. Hepatol. 2013, 10, 656-665. [CrossRef] [PubMed]

98. Pepe, F.; Lupini, L.; Ferracin, M.; Braconi, C.; Callegari, E.; Pagotto, S.; Spizzo, R.; Zagatti, B.; Lanuti, P.; Fornari, F.; et al. Over-expression of the miR-483-3p overcomes the miR-145/TP53 pro-apoptotic loop in hepatocellular carcinoma. Oncotarget 2016, 7, 31361.

99. Sachdeva, M.; Mo, Y.Y. MicroRNA-145 suppresses cell invasion and metastasis by directly targeting mucin 1 . Cancer Res. 2010, 70, 378-387. [CrossRef] [PubMed]

100. Xu, N.; Papagiannakopoulos, T.; Pan, G.; Thomson, J.A.; Kosik, K.S. MicroRNA-145 regulates OCT4, SOX2, and KLF4 and represses pluripotency in human embryonic stem cells. Cell 2009, 137, 647-658. [CrossRef] [PubMed]

101. Shi, B.; Sepp-Lorenzino, L.; Prisco, M.; Linsley, P.; deAngelis, T.; Baserga, R. Micro RNA 145 targets the insulin receptor substrate-1 and inhibits the growth of colon cancer cells. J. Biol. Chem. 2007, 282, 32582-32590. [CrossRef] [PubMed]

102. Sachdeva, M.; Mo, Y.Y. P53 and c-MYC: How does the cell balance "yin" and "yang"? Cell Cycle 2009, 8, 1303. [CrossRef] [PubMed]

103. Cho, W.C.; Chow, A.S.; Au, J.S. MiR-145 inhibits cell proliferation of human lung adenocarcinoma by targeting EGFR and NUDT1. RNA Biol. 2011, 8, 125-131. [CrossRef] [PubMed]

104. Zhang, J.; Sun, Q.; Zhang, Z.; Ge, S.; Han, Z.G.; Chen, W.T. Loss of microRNA-143/145 disturbs cellular growth and apoptosis of human epithelial cancers by impairing the MDM2-p53 feedback loop. Oncogene 2013, 32, 61-69. [CrossRef] [PubMed]

105. Iorio, M.V.; Ferracin, M.; Liu, C.G.; Veronese, A.; Spizzo, R.; Sabbioni, S.; Magri, E.; Pedriali, M.; Fabbri, M.; Campiglio, M.; et al. MicroRNA gene expression deregulation in human breast cancer. Cancer Res. 2005, 65, 7065-7070. [CrossRef] [PubMed]

106. Bandres, E.; Cubedo, E.; Agirre, X.; Malumbres, R.; Zarate, R.; Ramirez, N.; Abajo, A.; Navarro, A.; Moreno, I.; Monzo, M.; et al. Identification by real-time PCR of 13 mature microRNAs differentially expressed in colorectal cancer and non-tumoral tissues. Mol. Cancer 2006, 5, 29. [CrossRef] [PubMed]

107. Gramantieri, L.; Ferracin, M.; Fornari, F.; Veronese, A.; Sabbioni, S.; Liu, C.G.; Calin, G.A.; Giovannini, C.; Ferrazzi, E.; Grazi, G.L.; et al. Cyclin G1 is a target of miR-122a, a microRNA frequently down-regulated in human hepatocellular carcinoma. Cancer Res. 2007, 67, 6092-6099. [CrossRef] [PubMed]

108. Iorio, M.V.; Visone, R.; Di Leva, G.; Donati, V.; Petrocca, F.; Casalini, P.; Taccioli, C.; Volinia, S.; Liu, C.G.; Alder, H.; et al. MicroRNA signatures in human ovarian cancer. Cancer Res. 2007, 67, 8699-8707. [CrossRef] [PubMed]

109. Ozen, M.; Creighton, C.J.; Ozdemir, M.; Ittmann, M. Widespread deregulation of microRNA expression in human prostate cancer. Oncogene 2008, 27, 1788-1793. [CrossRef] [PubMed]

110. Liu, X.; Sempere, L.F.; Galimberti, F.; Freemantle, S.J.; Black, C.; Dragnev, K.H.; Ma, Y.; Fiering, S.; Memoli, V.; Li, H.; et al. Uncovering growth-suppressive microRNAs in lung cancer. Clin. Cancer Res. 2009, 15, 1177-1183. [CrossRef] [PubMed]

111. Spizzo, R.; Nicoloso, M.S.; Lupini, L.; Lu, Y.; Fogarty, J.; Rossi, S.; Zagatti, B.; Fabbri, M.; Veronese, A.; Liu, X.; et al. MiR-145 participates with tp53 in a death-promoting regulatory loop and targets estrogen receptor-alpha in human breast cancer cells. Cell Death Differ. 2010, 17, 246-254. [CrossRef] [PubMed]

112. Suzuki, H.I.; Yamagata, K.; Sugimoto, K.; Iwamoto, T.; Kato, S.; Miyazono, K. Modulation of microRNA processing by p53. Nature 2009, 460, 529-533. [CrossRef] [PubMed]

113. De Queiroz, R.M.; Madan, R.; Chien, J.; Dias, W.B.; Slawson, C. Changes in O-linked N-acetylglucosamine (O-glcnac) homeostasis activate the p53 pathway in ovarian cancer cells. J. Biol. Chem. 2016, 291, 18897-18914. [CrossRef] [PubMed] 
114. Zhou, W.; Yang, W.; Ma, J.; Zhang, H.; Li, Z.; Zhang, L.; Liu, J.; Han, Z.; Wang, H.; Hong, L. Role of miR-483 in digestive tract cancers: From basic research to clinical value. J. Cancer 2018, 9, 407-414. [CrossRef] [PubMed]

115. Ma, J.; Hong, L.; Xu, G.; Hao, J.; Wang, R.; Guo, H.; Liu, J.; Zhang, Y.; Nie, Y.; Fan, D. MiR-483-3p plays an oncogenic role in esophageal squamous cell carcinoma by targeting tumor suppressor EI24. Cell Biol. Int. 2016, 40, 448-455. [CrossRef] [PubMed]

116. Abue, M.; Yokoyama, M.; Shibuya, R.; Tamai, K.; Yamaguchi, K.; Sato, I.; Tanaka, N.; Hamada, S.; Shimosegawa, T.; Sugamura, K.; et al. Circulating miR-483-3p and miR-21 is highly expressed in plasma of pancreatic cancer. Int. J. Oncol. 2015, 46, 539-547. [CrossRef] [PubMed]

117. Wang, C.; Sun, Y.; Wu, H.; Yu, S.; Zhang, L.; Meng, Y.; Liu, M.; Yang, H.; Liu, P.; Mao, X.; et al. Elevated $m i R-483-3 p$ expression is an early event and indicates poor prognosis in pancreatic ductal adenocarcinoma. Tumour Biol. 2015, 36, 9447-9456. [CrossRef] [PubMed]

118. Fischer, D.; Wahlfors, T.; Mattila, H.; Oja, H.; Tammela, T.L.; Schleutker, J. MiRNA profiles in lymphoblastoid cell lines of finnish prostate cancer families. PLoS ONE 2015, 10, e127427. [CrossRef] [PubMed]

119. Lv, Y.; Qi, R.; Xu, J.; Di, Z.; Zheng, H.; Huo, W.; Zhang, L.; Chen, H.; Gao, X. Profiling of serum and urinary microRNAs in children with atopic dermatitis. PLoS ONE 2014, 9, e115448. [CrossRef] [PubMed]

120. Bay, A.; Coskun, E.; Oztuzcu, S.; Ergun, S.; Yilmaz, F.; Aktekin, E. Plasma microRNA profiling of pediatric patients with immune thrombocytopenic purpura. Blood Coagul. Fibrinolysis 2014, 25, 379-383. [CrossRef] [PubMed]

121. Zhang, Z.; Ge, S.; Wang, X.; Yuan, Q.; Yan, Q.; Ye, H.; Che, Y.; Lin, Y.; Zhang, J.; Liu, P. Serum miR-483-5p as a potential biomarker to detect hepatocellular carcinoma. Hepatol. Int. 2013, 7, 199-207. [CrossRef] [PubMed]

122. Wang, H.J.; Zhang, P.J.; Chen, W.J.; Feng, D.; Jia, Y.H.; Xie, L.X. Four serum microRNAs identified as diagnostic biomarkers of sepsis. J. Trauma Acute Care Surg. 2012, 73, 850-854. [CrossRef] [PubMed]

123. Xue, L.; Nan, J.; Dong, L.; Zhang, C.; Li, H.; Na, R.; He, H.; Wang, Y. Upregulated miR-483-5p expression as a prognostic biomarker for esophageal squamous cell carcinoma. Cancer Biomark. Sect. A Dis. Markers 2017, 19, 193-197. [CrossRef] [PubMed]

124. Harling, L.; Lambert, J.; Ashrafian, H.; Darzi, A.; Gooderham, N.J.; Athanasiou, T. Elevated serum microRNA 483-5p levels may predict patients at risk of post-operative atrial fibrillation. Eur. J. Cardio-Thorac. Surg. 2017, 51, 73-78. [CrossRef] [PubMed]

125. Kong, D.; Piao, Y.S.; Yamashita, S.; Oshima, H.; Oguma, K.; Fushida, S.; Fujimura, T.; Minamoto, T.; Seno, H.; Yamada, Y.; et al. Inflammation-induced repression of tumor suppressor miR-7 in gastric tumor cells. Oncogene 2012, 31, 3949-3960. [CrossRef] [PubMed]

126. Wang, W.; Zhao, L.J.; Tan, Y.X.; Ren, H.; Qi, Z.T. MiR-138 induces cell cycle arrest by targeting cyclin d3 in hepatocellular carcinoma. Carcinogenesis 2012, 33, 1113-1120. [CrossRef] [PubMed]

127. Wang, W.; Zhao, L.J.; Tan, Y.X.; Ren, H.; Qi, Z.T. Identification of deregulated miRNAs and their targets in hepatitis b virus-associated hepatocellular carcinoma. World J. Gastroenterol. 2012, 18, 5442-5453. [CrossRef] [PubMed]

128. Yi, C.; Wang, Q.; Wang, L.; Huang, Y.; Li, L.; Liu, L.; Zhou, X.; Xie, G.; Kang, T.; Wang, H.; et al. MiR-663, a microRNA targeting p21 (WAF1/CIP1), promotes the proliferation and tumorigenesis of nasopharyngeal carcinoma. Oncogene 2012, 31, 4421-4433. [CrossRef] [PubMed]

129. Zhang, M.; Liu, D.; Li, W.; Wu, X.; Gao, C.; Li, X. Identification of featured biomarkers in breast cancer with microRNA microarray. Arch. Gynecol. Obstet. 2016, 294, 1047-1053. [CrossRef] [PubMed]

130. Li, F.; Ma, N.; Zhao, R.; Wu, G.; Zhang, Y.; Qiao, Y.; Han, D.; Xu, Y.; Xiang, Y.; Yan, B.; et al. Overexpression of $m i R-483-5 p / 3 p$ cooperate to inhibit mouse liver fibrosis by suppressing the tgf-beta stimulated hscs in transgenic mice. J. Cell. Mol. Med. 2014, 18, 966-974. [CrossRef] [PubMed]

131. Fornari, F.; Milazzo, M.; Galassi, M.; Callegari, E.; Veronese, A.; Miyaaki, H.; Sabbioni, S.; Mantovani, V.; Marasco, E.; Chieco, P.; et al. p53/MDM2 feedback loop sustains miR-221 expression and dictates the response to anticancer treatments in hepatocellular carcinoma. Mol. Cancer Res. MCR 2014, 12, $203-216$. [CrossRef] [PubMed]

132. Pollutri, D.; Gramantieri, L.; Bolondi, L.; Fornari, F. Tp53/microRNA interplay in hepatocellular carcinoma. Int. J. Mol. Sci. 2016, 17, 2029. [CrossRef] [PubMed]

133. Garofalo, M.; Di Leva, G.; Romano, G.; Nuovo, G.; Suh, S.S.; Ngankeu, A.; Taccioli, C.; Pichiorri, F.; Alder, H.; Secchiero, P.; et al. MiR-221E222 regulate trail resistance and enhance tumorigenicity through pten and timp3 downregulation. Cancer Cell 2009, 16, 498-509. [PubMed] 
134. Zhang, C.Z.; Zhang, J.X.; Zhang, A.L.; Shi, Z.D.; Han, L.; Jia, Z.F.; Yang, W.D.; Wang, G.X.; Jiang, T.; You, Y.P.; et al. MiR-221 and miR-222 target puma to induce cell survival in glioblastoma. Mol. Cancer 2010, 9, 229. [CrossRef] [PubMed]

135. Meacham, C.E.; Morrison, S.J. Tumour heterogeneity and cancer cell plasticity. Nature 2013, 501, $328-337$. [CrossRef] [PubMed] 